Bradish, C. J. \& Brooksby, J. B. (1960). J. gen. Microbiol. 22, 405-415

\title{
Complement-fixation Studies of the Specificity of the Interactions between Components of the Virus System of Foot-and-Mouth Disease and its Antibodies
}

\author{
By C. J. BRADISH AND J. B. BROOKSBY \\ Research Institute (Animal Virus Diseases), Pirbright, Surrey
}

\begin{abstract}
SUMMARY : The type and subtype specificities of the interactions between fractions of the virus system of foot-and-mouth disease and its antibodies were investigated by complement-fixation methods. Specificity is discussed in terms of a cross-fixation ratio. The $25 \mathrm{~m} \mu$ infective component (D-fraction) combines homotypically with antibody. Thermal degradation of the $25 \mathrm{~m} \mu$ component produces a smaller component of enhanced activity which combines heterotypically with antibody and resembles the naturally occurring $7 \mathrm{~m} \mu$ component (U-fraction). The influence of heating upon the $7 \mathrm{~m} \mu$ component is marked by a sharpened specificity. The specificity and activity of unfractionated starting materials may be interpreted in terms of those of the 25 and $7 \mathrm{~m} \mu$ components present in the separable fractions. Significant differences between the reactions observed in the long and short incubation procedures emphasize the advantages of the latter in specificity studies. The composition and treatment of the initial antigens and the test procedures employed must be carefully defined in such studies of antigen-antibody combination.
\end{abstract}

As in other systems of multiple antigens and antibodies, viral antigenantibody interactions reveal affinities which are discussed under the term 'specificity'. As the component antigens and antibodies become more and more exactly defined it is necessary to refine the definition of specificity to distinguish between the different specificities of the individual components and the ill-defined hybrid specificity of the original material in which these components occur in variable if not unknown proportions. In the particular case of the infective agent in the virus system of foot-and-mouth disease higher and higher specificities are involved in the progression from the recognition of a virus as that of foot-and-mouth disease, to the recognition of the virus as one of the seven distinct types within the disease group, and then to the recognition of that virus as a distinct subtype within the type. The further specificity defined by the adaptation of the virus to a particular animal host is outside the scope of the present study. Superimposed upon this progression of specificities for the infective agent there are the related yet distinct specificities of other antigens within the virus system.

This paper reports a study by complement fixation of the type specificities of the components of the virus system of foot-and-mouth disease. Earlier studies on unfractionated materials and parts of the present work were reviewed by Brooksby (1953, 1958). Recent gel-diffusion studies by Brown \& Crick (1958) have confirmed some of the present findings. 


\section{METHODS}

The antigens and antibodies used in these experiments and the methods of titration of infectivity and complement-fixing activity were as described in previous papers (Brooksby, 1952; Bradish, Brooksby \& Tsubahara, 1960).

The starting materials for fractionation were pooled suspensions of the vesicular epithelium and fluid from primary lesions on the plantar pads of groups of 20 or more infected guinea pigs. Original suspensions of $1 \mathrm{~g}$. tissue in $10 \mathrm{ml}$. phosphate buffer $(\mathrm{M} / 25 ; \mathrm{pH} 7 \cdot 6)$ provided clarified starting materials containing about $5 \mathrm{mg}$. protein $/ \mathrm{ml}$. The separation by centrifugation of the components of the virus system proceeded as previously described (Bradish, Brooksby, Dillon \& Norambuena, 1952; Bradish, Henderson \& Kirkham, 1960). The distribution of infectivity, complement-fixing activity and nitrogen through the various fractions was described in the latter paper. The $25 \mathrm{~m} \mu$ infective component occurs in the D-fraction and the $7 \mathrm{~m} \mu$ complement-fixing component in the $\mathrm{U}$-fraction.

\section{Definition of specificity and cross-fixation ratio}

Specificity studies, in general, involve the comparison of two reactions in which one reactant, either antigen or antibody, is common to both. In terms of complement fixation the combination reactions between antigen $G_{1}$ and antibody $B$ and between antigen $G_{2}$ and the same antibody $B$ are arranged in order of specificity according to the amount of complement fixed in appropriately standardized tests in which the antigen concentrations $\left(G_{1}\right)$ and $\left(G_{2}\right)$ are equal. The more specific reaction fixes the greater amount of complement.

The ratio of the two complement-fixing activities observed when equal samples of an antigen react in standardized tests with antisera $A$ and $B$ may be expressed as

Cross-fixation ratio $=\frac{\begin{array}{l}\text { complement-fixing activity in presence of excess } \\ \text { antibody } B\end{array}}{\begin{array}{l}\text { complement-fixing activity in presence of excess } \\ \text { antibody } A\end{array}}$

This ratio is independent of the unknown antigen concentration and provides a measure of the specificity of the combination between antigen and antibody $B$ in terms of that between the same antigen and antibody $A$ (see previous paper; Bradish, Brooksby \& Tsubahara, 1960). When the antibody $\mathbf{A}$ is defined as that homologous to the antigen then the cross-fixation ratio ranges from zero for the reaction between completely heterologous antigen and antibody, to unity for the reaction between homologous reactants. This convenient scale of cross-fixation is the basis of the interpretation of the present data.

The comparison between two antigens in complement-fixation tests using the corresponding two homologous antisera requires the further definition: two antigens are distinct when the product of their cross-fixation ratios, 
tested in excess of the homologous antisera, is significantly different from unity. A similar definition applies to the data of antibody titrations in antigen excess, when the terminology is adjusted accordingly. The application of this criterion to type and subtype differentiation is shown below.

\section{RESUL'TS}

\section{Cross-fixation ratios of $U$ - and $D$-fractions}

Complement-fixation data for the titration in antibody excess of fractions of the virus system are shown in Table 1. Experiments in which the antigen-antibody mixture was incubated with complement for $30 \mathrm{~min}$. at $37^{\circ}$ before the introduction of the haemolytic indicator (short test) showed the typical degrees of complement-fixing activity and specificity associated with the $\mathrm{U}(7 \mathrm{~m} \mu$ component) and $\mathrm{D}(25 \mathrm{~m} \mu$ component) fractions. The fixation of complement by the clarified starting material in the presence of type-homologous serum was sufficiently in excess of that observed in excess of typeheterologous serum to ensure a correct designation of type in most cases. This

Table 1. Specificity of fractions of the virus system of foot-and-mouth disease separated from guinea-pig pad epithelium and vesicular fluid

Activities are shown in the body of the table as the volumes ( $\mu l$.$) of complement 'fixed'$ in antibody excess by $1 \mathrm{ml}$. the undiluted virus fractions. The concentrations of all fractions are the same as those of the clarified starting materials.

\begin{tabular}{|c|c|c|c|c|c|c|c|}
\hline \multicolumn{2}{|c|}{ Type and strain } & \multicolumn{2}{|c|}{ Starting material } & \multicolumn{2}{|c|}{ U-fraction } & \multicolumn{2}{|c|}{ D-fraction } \\
\hline $\begin{array}{l}\text { fraction of virus } \\
\text { titrated }\end{array}$ & $\begin{array}{l}\text { of excess } \\
\text { antiserum }\end{array}$ & $\begin{array}{l}\text { Long } \\
\text { test }\end{array}$ & $\begin{array}{l}\text { Short } \\
\text { test }\end{array}$ & $\begin{array}{l}\text { Long } \\
\text { test }\end{array}$ & $\begin{array}{l}\text { Short } \\
\text { test }\end{array}$ & $\begin{array}{l}\text { Long } \\
\text { test }\end{array}$ & $\begin{array}{l}\text { Short } \\
\text { test }\end{array}$ \\
\hline \multirow[t]{3}{*}{$\mathbf{O} / \mathbf{V I}$} & A/GB & 980 & - & 440 & 一 & 6 & - \\
\hline & C/GC & 1010 & - & 460 & - & 3 & - \\
\hline & O/VI & 1550 & 一 & 630 & - & 41 & - \\
\hline \multirow{2}{*}{$\begin{array}{l}\text { Cross-fixation } \\
\text { ratio }\end{array}$} & $\int$ To A & 0.63 & 一 & $0 \cdot 70$ & - & $0 \cdot 15$ & - \\
\hline & $\{$ To C & $0 \cdot 65$ & - & 0.73 & - & 0.07 & 一 \\
\hline \multirow[t]{2}{*}{ O/VI } & $\mathrm{A} / \mathbf{8 5}$ & - & - & 234 & 26 & 4 & 0.5 \\
\hline & $0 / 87$ & 621 & 218 & 253 & 98 & 25 & 17 \\
\hline $\begin{array}{l}\text { Cross-fixation } \\
\text { ratio }\end{array}$ & To A & - & - & 0.92 & $\mathbf{0} \cdot 27$ & $0 \cdot 16$ & $0 \cdot 03$ \\
\hline \multirow[t]{4}{*}{$\mathbf{A} / \mathbf{G B}$} & $\mathrm{A} / 78$ & - & 206 & - & 56 & - & 12 \\
\hline & $\mathrm{C} / 73$ & - & 19 & - & 14 & 一 & $0 \cdot 2$ \\
\hline & $0 / 74$ & 一 & 20 & - & 13 & - & $\mathbf{0}$ \\
\hline & Normal & - & $\mathbf{5}$ & - & $1 \cdot 3$ & - & $0 \cdot 2$ \\
\hline \multirow{2}{*}{$\begin{array}{l}\text { Cross-fixation } \\
\text { ratio }\end{array}$} & f To C & - & 0.09 & 一 & $0 \cdot 25$ & - & 0.02 \\
\hline & $\{$ To $O$ & - & $0 \cdot 10$ & 一 & $0 \cdot 23$ & - & 0 \\
\hline \multirow[t]{2}{*}{$\mathbf{A} / \mathbf{G B}$} & A/84 & 108 & 40 & 44 & 9 & 2 & 2 \\
\hline & $0 / 87$ & - & - & 19 & 2 & $\mathbf{0}$ & $\mathbf{0}$ \\
\hline $\begin{array}{l}\text { Cross-fixation } \\
\text { ratio }\end{array}$ & To $O$ & - & - & 0.43 & $0 \cdot 22$ & $>0.04$ & $>0.03$ \\
\hline \multirow[t]{3}{*}{ C/GC } & A/GB & 310 & - & 120 & - & 18 & - \\
\hline & C/GC & 780 & - & 240 & - & 47 & - \\
\hline & O/VI & 420 & - & 230 & - & 13 & - \\
\hline \multirow{2}{*}{$\begin{array}{l}\text { Cross-fixation } \\
\text { ratio }\end{array}$} & $\{$ To A & 0.40 & - & 0.50 & - & $0 \cdot 38$ & - \\
\hline & $\{$ To $O$ & 0.54 & - & 0.96 & - & $0 \cdot 28$ & - \\
\hline
\end{tabular}


is equivalent to the standard typing procedure (Brooksby, 1952). Separated U-fractions showed significantly greater cross-fixation than did the clarified starting materials.

The D-fractions, in contrast to the U-fractions, showed cross-fixation ratios which were sufficiently low to permit the conclusion that in the short incubation test the $25 \mathrm{~m} \mu$ component combined only with antibody of its own type and thereby defined the virus type of the starting material. Uncertainties in typing tests on unfractionated materials may be resolved by typing the separated homotypic D-fractions.

The fixation of complement by antigen-fractions in the presence of normal, inactivated guinea-pig serum was usually less than $2 \%$ of that in homologous serum.

Table 1 also shows results by the long-incubation test. Values of both complement-fixation and cross-fixation ratio were significantly greater in the long- than in the short-incubation test. This loss of specificity by the U-fraction in the long test was coupled with the disproportionate enhancement of activity demonstrated in the previous paper. It is apparent that the short-incubation test offers considerable advantages in sensitivity to virus type, particularly in typing studies of unfractionated starting materials.

In both long- and short-incubation tests the cross-fixation ratios for the D-fractions was significantly less, and for the U-fractions significantly more, than those for the starting materials. These data generally are consistent with the recognition of the starting material as a mixture of a homotypic $25 \mathrm{~m} \mu$ component and a heterotypic $7 \mathrm{~m} \mu$ component which respond differently to incubation procedures in the complement-fixation test.

Specificity in relation to sub-types of virus and corresponding antisera

In the previous section the cross-fixation ratio was shown to be determined by the virus fraction and incubation method used and to differentiate clearly between reactants of distinct virus type. Lower order variations in the properties of antigens and antibodies within a single virus type have been reported (Traub \& Möhlmann, 1946; Galloway, Henderson \& Brooksby, 1948). Such strains are called variants or subtypes.

Table 2 shows the complement-fixation data relating to two strains of virus of $\mathbf{A}$ type and three strains of $\mathrm{C}$ type. Titrations of antibody in antigen excess and of antigen in antibody excess are shown for the $U$ - and D-fractions of the virus systems. The cross-fixation ratio, now the ratio of the complementfixing activity in excess of strain-heterologous reactant to that in excess of strain-homologous reactant, is shown in Table 2 in brackets beside the corresponding complement-fixing activities. In all experiments, and as reported in the previous paper (Bradish, Brooksby \& Tsubahara, 1960), the titration of antibody in antigen excess allowed a more sensitive detection of differences than the alternative titration of antigen in antibody excess.

In the titrations of either antibody or U-fraction antigen of type A, strain Ca 1, the fixation with antigen or antibody of type A, strain GB, was greater than that with the strain-homologous reactants. A similar situation appears 
in the data for type C, strain 149, in Table 2 and for type A, strain HK. The remaining antigen-antibody combinations show greatest activities with strainhomologous reactants. These observations of $\mathbf{U}$-fraction activities in opposition to the subtype differentiation of the parent material emphasize the generally heterologous character of the $7 \mathrm{~m} \mu$ component of the virus system and the caution which must be exercised in the subtyping of unfractionated samples.

Table 2. Influence of variations within type on antigen-antibody combination reactions

All tests by long incubation method except where $\dagger$ indicates short incubation method. Activities in complement-fixation expressed as $\mathrm{ml} . \mathrm{C}^{\prime} / \mathrm{ml}$. undiluted sample (see Table 1) Cross-fixation ratios are shown in parentheses; (1) indicates the test with homologous reactants.

\begin{tabular}{|c|c|c|c|c|c|c|}
\hline \multirow{3}{*}{$\begin{array}{l}\text { Antigen: } \\
\text { type/strain/ } \\
\text { fraction }\end{array}$} & \multicolumn{3}{|c|}{$\begin{array}{c}\text { Titration of antibody with } \\
\text { excess antigen }\end{array}$} & \multicolumn{3}{|c|}{$\begin{array}{c}\text { Titration of antigen with excess } \\
\text { antibody }\end{array}$} \\
\hline & \multicolumn{6}{|c|}{ Type and strain of serum used as antibody } \\
\hline & A/GB & $\mathrm{A} / \mathrm{Ca} 1$ & & A/GB & $\mathrm{A} / \mathrm{Ca} \mathbf{1}$ & \\
\hline \multirow[t]{2}{*}{$\mathbf{A} / \mathbf{C a} \mathbf{1} / \mathrm{U}$} & $48(0 \cdot 15)$ & $16(1)$ & - & $0 \cdot 140(1 \cdot 6)$ & $0 \cdot 086(1)$ & - \\
\hline & & & & $\dagger 0.028(1 \cdot 2)$ & †0.023 (1) & - \\
\hline \multirow[t]{2}{*}{$\mathrm{A} / \mathrm{Ca} 1 / \mathrm{D}$} & - & $41(1)$ & - & $0.049(0.95)$ & $0.052(1)$ & - \\
\hline & & & & $\dagger 0.029(0.97)$ & †0.030 (1) & - \\
\hline \multirow[t]{2}{*}{$\mathbf{A} / \mathbf{G B} / \mathbf{U}$} & $330(1)$ & $31(2)$ & - & $0.260(1)$ & $0 \cdot 130(0 \cdot 5)$ & - \\
\hline & & & & $\dagger 0.082(1)$ & $+0.038(0.46)$ & - \\
\hline \multirow[t]{3}{*}{ A/GB/D } & $390(1)$ & - & - & $0.072(1)$ & $0.038(0.53)$ & - \\
\hline & & & & †0.048 (1) & †0.029 $(0.60)$ & - \\
\hline & $\mathrm{C} / 149$ & $\mathrm{C} / 733$ & $\mathbf{C} / \mathbf{U} 3$ & $\mathrm{C} / \mathbf{1 4 9}$ & $\mathrm{C} / 733$ & C/U3 \\
\hline $\mathrm{C} / 149 / \mathrm{U}$ & $38(1)$ & $44(0.5)$ & $75(1 \cdot 2)$ & $0.41(1)$ & $0.50(1$ & $0.61(1.5)$ \\
\hline $\mathrm{C} / 149 / \mathrm{D}$ & $38(1)$ & - & - & $0.69(1)$ & $0.67(0.97)$ & $0.59(0.85)$ \\
\hline $\mathrm{C} / 733 / \mathrm{U}$ & $70(1 \cdot 8)$ & $88(1)$ & $75(1 \cdot 2)$ & $0.47(9.00)$ & $0.52(1)$ & $0.45(0.86)$ \\
\hline $\mathrm{C} / 733 / \mathrm{D}$ & - & $130(1)$ & - & $0.40(0.85)$ & $0.47(1)$ & $0.41(0.87)$ \\
\hline $\mathbf{C} / \mathbf{U 3} / \mathbf{U}$ & $44(1 \cdot 2)$ & $40(0.46)$ & $63(1)$ & $0.42(0.70)$ & $0.58(0.97)$ & $0.60(1)$ \\
\hline C/U3/D & - & - & $190(1)$ & $0.70(0.69)$ & $0.85(0.83)$ & $1.02(1)$ \\
\hline
\end{tabular}

In terms of the product of cross-fixation ratios (Table 3 ) the virus strains GB and $\mathrm{Cal}$ of type $\mathrm{A}$ are distinct subtypes. This is shown also by the more sensitive titration of the antisera in antigen excess. The type $\mathrm{C}$ strain $\mathrm{U} 3$ is probably distinct from strains 733 and 149 , whereas the latter show no significant differentiation. In earlier studies of unfractionated materials (Skinner, Henderson \& Brooksby, 1952) strains 733 and 149 were identified as subtypes; this discrepancy has not been investigated further. Table 3 also shows the cross-fixation ratios appropriate to type differentiation studies and demonstrates the relatively small difference between subtypes as compared with that between types.

\section{Change of antigen activity produced by heat treatment}

Since the extent and specificity of antigen-antibody combination, as indicated by the complement-fixation test, is dependent upon the time-temperature conditions of incubation a number of experiments were made to examine 
the stability of the antigens during heating. Clarified starting materials and the derived $U$ - and $D$-fractions were heated in water baths at temperatures between $35^{\circ}$ and $56^{\circ}$ for periods up to $24 \mathrm{hr}$. Control samples were held at $4^{\circ}$. After treatment samples were cooled to $4^{\circ}$ until titrated by complement fixation in antibody excess. Typical results are shown in Fig. 1. When incubated at $35^{\circ}-40^{\circ}$ the complement-fixing activities of the D-fractions increased steadily until at 16-24 $\mathrm{hr}$. the activities were about twice those of the control

Table 3. Differentiation of foot-and-mouth disease virus strains as types and subtypes

\begin{tabular}{|c|c|c|c|}
\hline $\begin{array}{l}\text { Virus type of } \\
\text { strains used }\end{array}$ & $\begin{array}{l}\text { Strains and fractions } \\
\text { under comparison }\end{array}$ & $\begin{array}{l}\text { Cross-fixation } \\
\text { ratio in } \\
\text { long and short } \\
\text { tests }\end{array}$ & $\begin{array}{l}\text { Product of } \\
\text { cross-fixation } \\
\text { ratios }\end{array}$ \\
\hline \multirow[t]{3}{*}{$\mathbf{A}$} & $\begin{array}{l}\text { Ca 1-fraction } \\
\text { GB-U fraction }\end{array}$ & $\begin{array}{c}1 \cdot 6,1 \cdot 2 \\
0 \cdot 50,0 \cdot 46\end{array}$ & $0.8,0.55$ \\
\hline & $\begin{array}{l}\text { Ca 1-U fraction } \\
\text { GB-D fraction }\end{array}$ & $\begin{array}{l}0.95,0.97 \\
0.53,0.60\end{array}$ & $0.50,0.58$ \\
\hline & $\begin{array}{l}\text { Ca 1-antiserum } \\
\text { GB-antiserum }\end{array}$ & $\begin{array}{l}2 \cdot 0 \\
0 \cdot 15\end{array}$ & $0 \cdot 3$ \\
\hline \multirow[t]{9}{*}{$\mathbf{C}$} & $\begin{array}{l}\text { 149-U fraction } \\
733-U \text { fraction }\end{array}$ & $\begin{array}{l}1.2 \\
0 \cdot 90\end{array}$ & 1.08 \\
\hline & $\begin{array}{l}\text { 149-U fraction } \\
\text { U3-U fraction }\end{array}$ & $\begin{array}{l}1.5 \\
0.70\end{array}$ & $1 \cdot 05$ \\
\hline & $\begin{array}{l}\text { 733-U fraction } \\
\text { U3-U fraction }\end{array}$ & $\begin{array}{l}0 \cdot 86 \\
0.97\end{array}$ & 0.83 \\
\hline & $\begin{array}{l}\text { 149-U fraction } \\
\text { 733-D fraction }\end{array}$ & $\begin{array}{l}0 \cdot 97 \\
0 \cdot 85\end{array}$ & $0 \cdot 82$ \\
\hline & $\begin{array}{l}\text { 149-D fraction } \\
\text { U3-D fraction }\end{array}$ & $\begin{array}{l}0 \cdot 85 \\
0 \cdot 69\end{array}$ & 0.59 \\
\hline & $\begin{array}{l}\text { 733-D-fraction } \\
\text { U3-D fraction }\end{array}$ & $\begin{array}{l}0 \cdot 87 \\
0 \cdot 83\end{array}$ & $0 \cdot 72$ \\
\hline & $\begin{array}{l}\text { 149-antiserum } \\
\text { 733-antiserum }\end{array}$ & $\begin{array}{l}1 \cdot 8 \\
0 \cdot 5\end{array}$ & $0 \cdot 9$ \\
\hline & $\begin{array}{l}\text { 149-antiserum } \\
\text { U3-antiserum }\end{array}$ & $\begin{array}{l}1 \cdot 2 \\
1 \cdot 2\end{array}$ & $1 \cdot 4$ \\
\hline & $\begin{array}{l}\text { 733-antiserum } \\
\text { U3-antiserum }\end{array}$ & $\begin{array}{l}0 \cdot 46 \\
1 \cdot 2\end{array}$ & 0.55 \\
\hline \multicolumn{4}{|c|}{ Comparative type-differentiation } \\
\hline \multirow[t]{2}{*}{$A$ and $O$} & $\begin{array}{l}\text { A/GB-U fraction } \\
\text { O/VI-U fraction }\end{array}$ & $\begin{array}{l}0 \cdot 43,0 \cdot 22 \\
0 \cdot 92,0 \cdot 27\end{array}$ & $0.40,0.06$ \\
\hline & $\begin{array}{l}\text { A/GB-D fraction } \\
\text { O/VI-D fraction }\end{array}$ & $\begin{array}{l}0 \cdot 04,0 \cdot 03 \\
0 \cdot 16,0 \cdot 03\end{array}$ & $0.006,0.001$ \\
\hline
\end{tabular}

samples. Incubation for up to $30 \mathrm{~min}$. at $56^{\circ}$ or for $1-4 \mathrm{hr}$. at $45^{\circ}$ was sufficient to produce the same approximate doubling of the initial activity. Continued heating at $45^{\circ}$ for up to $24 \mathrm{hr}$. produced no significant loss of activity. In eleven such experiments at temperatures between $35^{\circ}$ and $56^{\circ}$ the complementfixing activities of D-fractions increased on the average to $190 \%(150-230 \%)$ of the initial values. Parallel incubation of the corresponding U-fractions 
(Fig. 1) showed a distinct behaviour since now the complement-fixing activities decreased in all cases. The activities fell to about $75 \%$ of the initial values after $16 \mathrm{hr}$. at $35^{\circ}-40^{\circ}$ or $1 \mathrm{hr}$. at $50^{\circ}-56^{\circ}$.

The results obtained in these experiments by the short and long incubation tests were generally similar, although differences in detail were apparent under certain conditions. Figure 2 shows the comparison of the results by the two methods, expressed as the ratio of the complement-fixing activity in the long incubation test to that in the short incubation test. This ratio of the

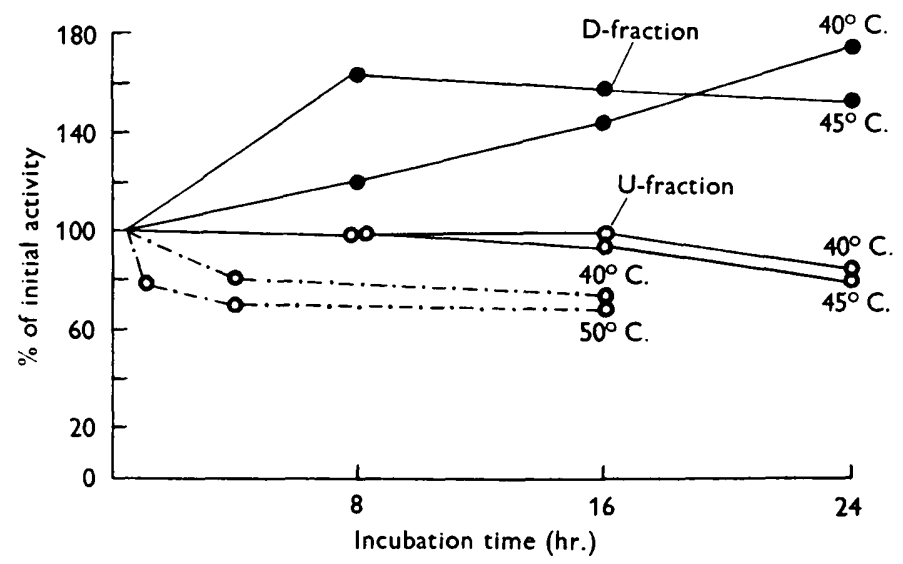

Fig. 1. Influence of heating upon complement-fixing activities of $U$ - and D-fractions of virus system. - $-\mathrm{D}$-fraction experiments; $\mathrm{O}-\mathrm{O}, \mathrm{O}-\mathrm{O} \mathrm{O} \mathrm{U}$-fraction experiments.

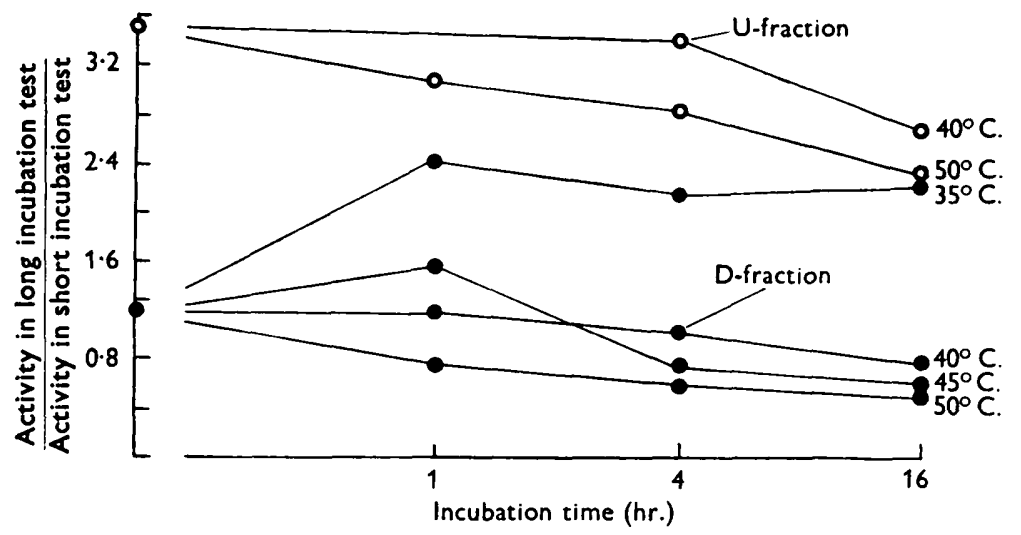

Fig. 2. Influence of heating of U- and D-fractions upon activities observed in long and short incubation tests.

test results is given for the $U$ - and D-fractions of the virus system after different thermal treatments. For the $U$-fraction the test ratio was initially 3.5 and fell steadily on heating to 2.3 after $16 \mathrm{hr}$. at $50^{\circ}$. For the D-fractions the test ratio was initially $\mathbf{1 . 3}$ and fell steadily with increasing time and temperatures above $40^{\circ}$ to values as low as $0 \cdot 6$. Treatment at $35^{\circ}$ for $1-16 \mathrm{hr}$., however, caused the test ratio to increase to about $2 \cdot 2$. This distinction of 
response between treatment at $35^{\circ}$ and $40^{\circ}$ or above is particularly interesting since the disintegration of the $25 \mathrm{~m} \mu$ component (D-fraction) at the lower temperature produced a component with test ratio akin to that of the $7 \mathrm{~m} \mu$ component (U-fraction). Degradation of either component at $40^{\circ}$ or above decreased the distinction between the tests. This suggests that part of the distinction between the tests is related to the degradation of the antigens during continued incubation with antibody.

\section{Change of specificity of antibody-combining activity following heat treatment of antigen fractions}

The data shown in Fig. 3 demonstrate the changes in specificity observed following heat treatment of the antigens for $4 \mathrm{hr}$. at $45^{\circ}$ or $56^{\circ}$. Heated and control fractions were titrated in antibody excess by complement fixation in the long-incubation test. The cross-fixation ratios show that the $\mathrm{D}$-fractions were initially almost completely type-specific in their capacity to combine
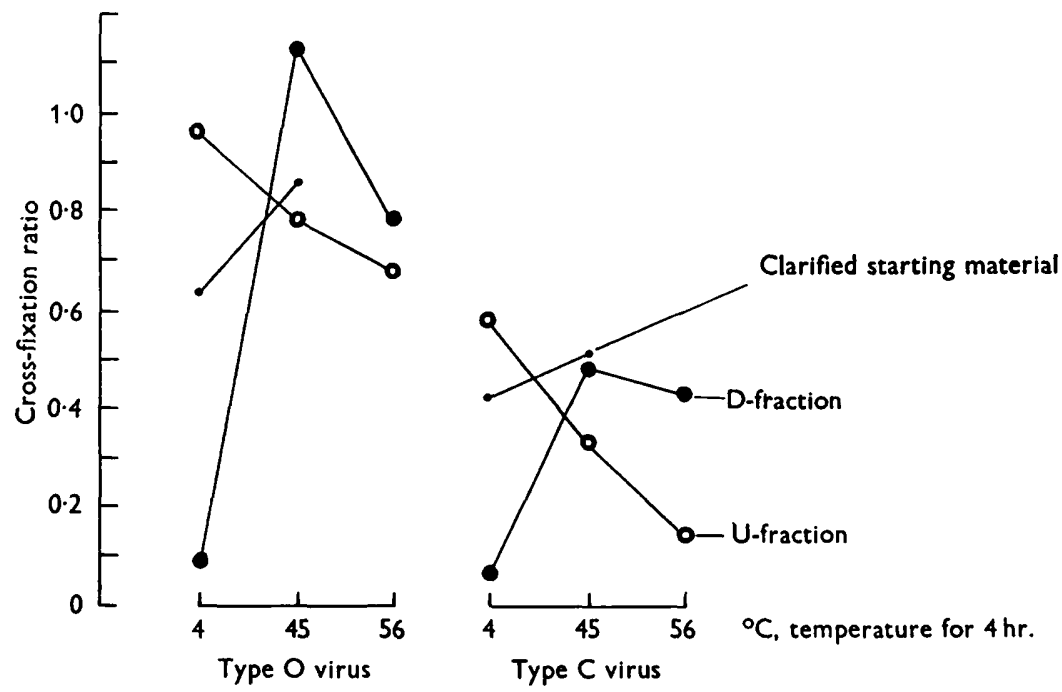

Fig. 3. Influence of heating upon antibody-combining specificities of fractions of virus system.

with antibody but became strongly heterotypic after heat treatment had doubled their homotypic capacity. In contrast to the D-fractions, heat treatment of the U-fractions improved the type-specificity of their combination with antibody. In some cases the heated U-fractions showed cross-fixation ratios approaching those of the highly specific initial $D$-fractions. The starting materials, regarded as natural mixtures of the $D$ - and $U$-fractions, showed properties intermediate between those of these components. Heat treatment of starting materials produced an increase of up to $c .50 \%$ in the value of complement-fixing activity in the presence of excess type-homologous antibody. This was accompanied by a slight increase in the degree of cross-fixation with antibody of heterologous type. 


\section{Change of sedimentation properties following heat treatment or storage of antigen fractions}

Sedimentation analyses of control or heated U-fractions by angle or radial tube sampling methods showed, in confirmation of earlier data (Bradish et al. 1952; Bradish, Brooksby \& Dillon, 1956), a complement-fixing component of sedimentation coefficient $8 \pm 1$ Svedberg units. This corresponds with an equivalent protein particle diameter of about $7 \mathrm{~m} \mu$, which was little changed by heat treatment under the conditions defined. Parallel experiments with the initial D-fractions indicated a particle size of about $25 \mathrm{~m} \mu$ by electron microscopy (Bradish, Henderson \& Kirkham, 1960) and a consistent minimum sedimentation coefficient of about 70 Svedberg units by angle or radial tube sampling methods, with assay by infectivity.

Table 4. Influence of heat treatment upon sedimentation properties of complement-fixing components of foot-and-mouth disease virus fractions

Virus used: type O/VI, guinea-pig material.

\begin{tabular}{|c|c|c|c|c|}
\hline \multirow[b]{2}{*}{ Fraction } & \multirow{2}{*}{$\begin{array}{c}\text { Initial } \\
\text { activity (\%) } \\
\text { relative to } \\
\text { clarified } \\
\text { starting } \\
\text { material } \\
\text { (c.s.m.) }\end{array}$} & \multicolumn{2}{|c|}{$\begin{array}{c}\text { Activity after heating at } \\
56^{\circ}(\% \text { initial c.s.m. })\end{array}$} & \multirow{2}{*}{$\begin{array}{c}\text { Percentage of } \\
\text { activity of } \\
\text { heated sample } \\
\text { remaining in } \\
\text { supernatant fluid } \\
\text { after centrifugation } \\
\text { at } 12 \mathrm{G} \text { to remove } \\
25 \mathrm{~m} \mu \text { component }\end{array}$} \\
\hline & & 15-30 min. & 1-2 hr. & \\
\hline $\begin{array}{l}\text { Clarified starting } \\
\text { material }\end{array}$ & 100 & - & 115 & 95 \\
\hline $\begin{array}{l}\text { U-fraction }(7 \mathrm{~m} \mu) \\
\text { D-fraction }(25 \mathrm{~m} \mu)\end{array}$ & $\begin{array}{l}41 \\
50\end{array}$ & - & $\begin{array}{l}25 \\
76\end{array}$ & $\begin{array}{l}80 \\
90\end{array}$ \\
\hline $\begin{array}{l}\text { U-fraction }(7 \mathrm{~m} \mu) \\
\text { D-fraction }(25 \mathrm{~m} \mu)\end{array}$ & $\begin{array}{l}50 \\
50\end{array}$ & $\begin{array}{l}34 \\
71\end{array}$ & $\begin{array}{l}30 \\
76\end{array}$ & $\begin{array}{l}75,85 \\
90,78\end{array}$ \\
\hline
\end{tabular}

Investigation of the sedimentation properties of thermally disintegrated D-fractions regularly showed a sedimentation coefficient of only 7 to 11 Svedberg units. Electron micrographs of such degraded $\mathbf{D}$-fractions showed in agreement with the sedimentation data, the absence of the $25 \mathrm{~m} \mu$ particle and the presence of aggregates and strings of 5-10 $\mathrm{m} \mu$ particles. Table 4 shows that after heat treatment the activity of the initially infective D-fractions sedimented as a $7 \mathrm{~m} \mu$ component, similar to that in the $\mathrm{U}$-fractions.

A complication in the interpretation of these experiments arose in some cases when analyses in terms of complement-fixing activity of unheated $D$-fractions gave sedimentation coefficients of about 8 Svedberg units. This indicated the lability of the $25 \mathrm{~m} \mu$ infective component, which may disintegrate more readily when partially purified than when present as a component of the starting material. It appears that the $25 \mathrm{~m} \mu$ component disintegrates continuously to produce an accumulating concentration of a smaller component of distinct properties. This process is accelerated by heating and also, to a lesser extent, by the manipulation inherent in experimental procedures. For this reason periods of manipulation at room temperature were restricted to a 
total of less than $2 \mathrm{hr}$. Final assays of the complement-fixing activity or infectivity of fractions were complete within 4-6 days of the collection of the initial infective materials.

That disintegration occurred even under the nominally favourable conditions of storage at $-20^{\circ}$ is indicated by the following experiment. Vesicular epithelium stripped from the tongue of a steer infected with virus of type 0 , strain 39, was divided into $1 \mathrm{~cm}$. squares and distributed in four $5 \mathrm{ml}$. bottles. An immediate partition analysis (Bradish et al. 1952) of the suspension prepared from the contents of one bottle indicated that $33 \%$ of total complementfixing activity was due to the $7 \mathrm{~m} \mu$ component. The remaining bottles were stored at $-20^{\circ}$ and suspensions were prepared for partition analysis after 1,4 and 14 weeks. After these times the complement-fixing activity due to the $7 \mathrm{~m} \mu$ component contributed, respectively, 49, 64 and almost $100 \%$ of the total activity. Thus even at $-20^{\circ}$ the proportion of total activity due to the extracted $25 \mathrm{~m} \mu$ component diminished from $67 \%$ initially to 51,36 and $0 \%$ at 1,4 and 14 weeks, respectively.

\section{DISCUSSION}

It had been shown earlier that the virus system of foot-and-mouth disease comprises at least two distinct components. The present study indicates, in terms of complement-fixation data, the serological specificity and interrelationship of these components. The $25 \mathrm{~m} \mu$ infective component which occurs in the separated $D$-fraction is a labile antigen which combines only with antibody of its own type. This component is readily degraded by heating to produce an essentially non-infective 7-11 $\mathrm{m} \mu$ component which combines with antibody of any type within the disease group. Such degradation is accompanied by an approximate doubling of complement-fixing activity in the presence of homologous antibody. The disintegration of the $25 \mathrm{~m} \mu$ infective component to produce a component which is similar in many respects to the naturally occurring $7 \mathrm{~m} \mu$ component suggests that this latter component may arise either as a precursor or as a product of the larger particle, or perhaps in both ways. In most starting materials collected from guinea pig or ox about half of the initial complement-fixing activity is due to the $7 \mathrm{~m} \mu$ component. If this arises through the disintegration of intact infective particles it might be anticipated that under certain conditions starting materials would be collected in which all complement-fixing activity was contributed by intact $25 \mathrm{~m} \mu$ particles. That such preparations are encountered only as separated D-fractions and not as starting materials implies either that disintegration proceeds as virus accumulates at the particular site in the host tissue, or that some $7 \mathrm{~m} \mu$ component is formed independently. The infectivity and complement-fixing activity of the material collected from the host may thus be dependent not only upon the course of virus multiplication but also upon superimposed decay processes.

In addition to the infective $25 \mathrm{~m} \mu$ component of complete type-specificity and the non-infective (probably only weakly antigenic) $7 \mathrm{~m} \mu$ particles pos- 
sessing only disease-group specificity, it is necessary to consider the presence of a non-infective yet fully antigenic component. The presence of such a $25 \mathrm{~m} \mu$ component is indicated by the 100- to 1000-fold disparity between particle counts by the electron microscope and titrations of numbers of infective units. The potency of vaccines also presumes a non-infective yet fully antigenic component. It is probable that non-infective $25 \mathrm{~m} \mu$ particles are responsible for the major part of the antigenicity and homotypic antibodycombining activity of virus samples. Such intermediate, non-infective components, which retain antigenicity or type-specificity, are of importance to the understanding of the relationships which exist between infectivity, antigenicity, antibody-combining capacity and physical-chemical structure.

The authors wish to thank Miss J. Rogers, Mr E. Scoates, and Mr W. Painter for their help in much of the complement-fixation work, and Mr T. Burrows and Miss H. Wigman for assistance in the separation procedures.

\section{REFERENCES}

Bradish, C. J., Brooksby, J. B., Dillon, J. F. \& Norambuena, M. (1952). Ultracentrifugal studies on the infective and complement-fixing components in the virus system of foot-and-mouth disease. Proc. roy. Soc. B, 140, 107.

Bradish, C. J., Brooksby, J. B. \& Dillon, Jun., J. F. (1956). Biophysical studies of the virus system of vesicular stomatitis. J. gen. Microbiol. 14, 290.

Bradish, C. J., Henderson, W. M. \& Kirkham, J. B. (1960). Concentration and electron microscopy of the characteristic particle of foot-and-mouth disease. J. gen. Microbiol. 22, 379.

Bradish, C. J., Brooksby, J. B. \& Tsubahara, H. (1960). The complement-fixation test in studies of the components of the virus system of foot-and-mouth disease and its antibodies. J. gen. Microbiol. 22, 392.

BrooksBy, J. B. (1952). The technique of complement-fixation in foot-and-mouth disease research. A.R.C. Rep. Ser. no. 12.

Brooksby, J. B. (1953). In The Nature of Virus Multiplication, Symp. Soc. gen. Microbiol. 2, 246.

Brooksby, J. B. (1958). The virus of foot-and-mouth disease. Advanc. Virus Res. 5, 1.

Brown, F. \& Crick, J. (1958). Application of agar gel precipitin tests to the study of the virus of foot-and-mouth disease. Virology, $5,133$.

Galloway, I. A., Henderson, W. M. \& Brooksby, J. B. (1948). Strains of the virus of foot-and-mouth disease recovered from outbreaks in Mexico. Proc. Soc. exp. Biol., N.Y. 69, 57.

Skinner, H. H., Henderson, W. M. \& Brooksby, J. B. (1952). Use of unweaned white mice in foot-and-mouth disease research. Nature, Lond. 169, 794.

Traub, E. \& Möhlmann, H. (1946). Untersuchungen über immunologische Varianten der Typen A und B des Maul-und-Klauenseuchevirus. Berl. Münch. tierärztl. Wschr. 1, 1. 